\title{
Adsorption of copper, cadmium and lead from aqueous solution to the kaolinite/water interface
}

\author{
P. W. Schindler ${ }^{1}$, P. Liechti ${ }^{1}$ and J. C. Westall ${ }^{2}$ \\ ${ }^{1}$ Department of Inorganic Chemistry, University of Bern, Freiestrasse 3, CH-3000 \\ Bern 9, Switzerland; \\ ${ }^{2}$ Department of Chemistry, Oregon State University, Corvallis, Oregon 97331 - \\ 4003, USA
}

Received 14 April 1987; accepted 16 June 1987

Key words: adsorption, cadmium, copper, ion exchange, lead, surface complexation, Vanselow coefficient

\begin{abstract}
The adsorption of $\mathrm{Cu}(\mathrm{II}), \mathrm{Cd}(\mathrm{II})$ and $\mathrm{Pb}(\mathrm{II})$ from aqueous solution to the kaolinite/ water interface has been studied at $298.2 \mathrm{~K}$ as a function of both $\mathrm{pH}$ and ionic strength of the aqueous phase. The extent of adsorption increases with increasing $\mathrm{pH}$ and with decreasing ionic strength. Both effects can be explained by a model that assumes two kinds of binding sites: a) weakly acidic groups XH that account for ion exchange, and b) ampholytic surface hydroxyls $\mathrm{SOH}$ which form inner sphere complexes with the divalent metal ions.
\end{abstract}

\section{Introduction}

The mobility of metal ions in the soil column and their availability to plants is largely governed by processes of the general scheme (Schindler, 1984; Tiller, 1986)

dissolved metal $\quad=$ particulate metal

Typical examples are:

$$
\begin{array}{ll}
\mathrm{Ca}^{2+}+2 \mathrm{HCO}_{3}^{-} & =\mathrm{CaCO}_{3(\mathrm{~s})}+\mathrm{CO}_{2(\mathrm{~g})}+\mathrm{H}_{2} \mathrm{O} \\
\mathrm{Al}^{3+}+3 \mathrm{H}_{2} \mathrm{O} & =\mathrm{Al}(\mathrm{OH})_{3(\mathrm{~s})}+3 \mathrm{H}^{+} \\
\mathrm{M}^{z+} \text {, oxide/clay particles } & =\mathrm{M}^{z+} \text { adsorbed at oxide/clay particles, } \mathrm{H}^{+}
\end{array}
$$

In many cases the reactions comprised by Equation 1 tend to approach the thermodynamic equilibrium. The partition of a given component between soil solution and 
soil minerals is then at least approximately described by the pertinent equilibrium constants. The classical approach (Lindsay, 1979) assumes pure solids as the controlling phases: the soil solution is understood as a saturated solution of the soil minerals present. Whereas this concept applies to components such as $\mathrm{Fe}$ (III) and $\mathrm{Mn}(\mathrm{IV})$, it was noted that observed concentrations of both $\mathrm{Cu}$ (II) and $\mathrm{Zn}$ (II) are much lower than those calculated on the basis of the solubilities of the corresponding oxides, hydroxides and carbonates (Lindsay, 1972). This suggests that the concentrations of some trace metals are controlled by adsorption/desorption reactions rather than by solubility equilibria (Ellis \& Knezek, 1972 and older literature quoted therein; Sposito, 1984a).

Adsorption of heavy metals at oxide/water interfaces can conveniently be described as surface complexation (Schindler, 1981; Sposito, 1984b; Westall, 1986; Schindler \& Stumm, 1987):

$$
\mathrm{nSOH}+\mathrm{M}^{\mathrm{z}+}=(\mathrm{SO})_{\mathrm{n}} \mathrm{M}^{(\mathrm{z}-\mathrm{n})+}+\mathrm{n} \mathrm{H}^{+}
$$

The uptake of heavy metals by clay minerals is obviously more complicated. At low $\mathrm{pH}$ values unspecific bonding based on electrostatic interaction of the hydrated metal ions with the negatively charged aluminosilicate matrix is the dominating process (McBride, 1976). X-ray photoelectron spectroscopy reveals that (for $\mathrm{Co}$ (II)-kaolinite) the chemical nature of the metal-clay interaction changes with increasing pH (Dillard \& Koppelman, 1982). This pH dependence of both the extent of heavy metal uptake and the nature of the metal-clay bond is in turn reflected by the fact (Menzel \& Jackson, 1951) that at elevated pH values the uptake of heavy metal ions is accompanied by a release of hydrogen ions. Moreover, uptake of heavy metals at elevated $\mathrm{pH}$ values seems to be much more specific than uptake at low pH. Farrah et al. (1980) thus concluded that the classical ion exchange model does not cover the whole range of adsorption phenomena and that part of the heavy metal adsorption occurs at sites created by displacement of protons from surface hydroxyls. This latter mode is indeed identical with the above mentioned surface complexation.

This paper reports on the uptake of $\mathrm{Cu}(\mathrm{II}), \mathrm{Cd}(\mathrm{II})$ and $\mathrm{Pb}(\mathrm{II})$ by kaolinite as a function of both $\mathrm{pH}$ and ionic strength. An attempt is made to explain the obtained data with a combined ion exchange-surface complexation model.

\section{Experimental part}

\section{Survey}

Portions of A kg of kaolinite were suspended in Vo $\mathrm{dm}^{3}$ of solutions $\mathrm{S} 1$ of the general composition

$$
\text { S1: } \begin{array}{rlr}
{\left[\mathrm{M}^{2+}\right]} & =\mathrm{Bo} & \mathrm{M} \\
{\left[\mathrm{H}^{+}\right]} & =\mathrm{Ho} & \mathrm{M} \\
{\left[\mathrm{Na}^{+}\right]} & =(\mathrm{I}-2 \mathrm{Bo}-\mathrm{Ho}) & \mathrm{M} \\
{\left[\mathrm{ClO}_{4}^{-}\right]} & =\mathrm{I} & \mathrm{M}
\end{array}
$$


and potentiometrically titrated at $298.2 \mathrm{~K}$ with $\mathrm{V} \mathrm{dm}{ }^{3}$ of solutions $\mathrm{S} 2$ of the general composition

$$
\begin{aligned}
& \text { S2: }\left[\mathrm{OH}^{-}\right]=\mathrm{Co} \quad \mathrm{M} \\
& {\left[\mathrm{Na}^{+}\right]=(\mathrm{Co}+\mathrm{I}) \quad \mathrm{M}} \\
& \text {, }\left[\mathrm{ClO}_{4}^{-}\right]=\mathrm{I} \quad \mathrm{M}
\end{aligned}
$$

After each addition of base and a subsequent equilibration time of 10 minutes, both $\left[\mathrm{H}^{+}\right]$and $\left[\mathrm{M}^{2+}\right]$ were obtained from electromotive force (emf) measurements with glass electrodes and $\mathrm{M}^{2+}$-specific electrodes. Some titrations were carried out in the absence of $\mathrm{M}^{2+}$. The parameters Bo and I were varied as follows:

$$
\mathrm{Bo} \approx 1 . \mathrm{E}-4 \mathrm{M}(9.1 \mathrm{E}-5 \mathrm{M}-9.9 \mathrm{E}-5 \mathrm{M}) \quad \mathrm{I}: 0.01,0.1,1.0 \mathrm{M}
$$

The ratio A/Vo was kept close to $0.02 \mathrm{~kg} / \mathrm{dm}^{3}$. The so obtained titration curves were reproducible but only partially reversible. This means that the subsequent application of equilibrium thermodynamics is only a first approximation.

The percentage of adsorbed divalent metal was obtained from

$$
\% \mathrm{M}(\mathrm{II})_{\mathrm{ads}}=100\left([\mathrm{M}(\mathrm{II})]_{\mathrm{t}}-[\mathrm{M}(\mathrm{II})]_{\mathrm{d}}\right) /[\mathrm{M}(\mathrm{II})]_{\mathrm{t}}
$$

The total concentration $[\mathrm{M}(\mathrm{II})]_{\mathrm{t}}$ of divalent metal in the suspension is given by

$$
[\mathrm{M}(\mathrm{II})]_{\mathrm{t}}=\mathrm{VoBo} /(\mathrm{Vo}+\mathrm{V})
$$

and the total concentration $[\mathrm{M}(\mathrm{II})]_{\mathrm{d}}$ of dissolved divalent metal is related to $\left[\mathrm{M}^{2+}\right]$ by

$$
[\mathrm{M}(\mathrm{II})]_{\mathrm{d}}=\left[\mathrm{M}^{2+}\right]\left(1+\sum * \beta_{\mathrm{n}}\left[\mathrm{H}^{+}\right]^{-\mathrm{n}}\right)
$$

where $* \beta_{\mathrm{n}}$ is the stability constant of the hydroxo complex $\mathrm{M}(\mathrm{OH})_{\mathrm{n}}{ }^{(2-\mathrm{n})+}$.

The experimental data were further combined to obtain $\mathrm{H}^{*}$, the number of moles of hydrogen ions per $\mathrm{dm}^{3}$ of solution that originates from the kaolinite-water interface:

$$
\mathrm{H} *=\left[\mathrm{H}^{+}\right]-\mathrm{H}_{\mathrm{a}}
$$

$\mathrm{H}_{\mathrm{a}}$, the analytical hydrogen ion concentration (i.e. the hydrogen ion concentration that one would observe in the absence of clay) is accessible from

$$
\mathrm{H}_{\mathrm{a}}=(\mathrm{VoHo}-\mathrm{VCo}) /(\mathrm{Vo}+\mathrm{V})+\left[\mathrm{OH}^{-}\right]+\Sigma \mathrm{n} * \beta_{\mathrm{n}}\left[\mathrm{M}^{2+}\right]\left[\mathrm{H}^{+}\right]^{-\mathrm{n}}
$$

The last term on the right hand side of Eq. 3 accounts for hydrogen ions formed in the course of the hydrolysis of $\mathrm{M}^{2+}$. 


\section{Materials}

Georgia kaolinite (KGa-1) was obtained from The Clay Minerals Society. The heteroionic material was repeatedly treated with $\mathrm{HClO}_{4}, \mathrm{H}_{2} \mathrm{O}_{2}$ and $\mathrm{NaOH}$. Details are given elsewhere (Liechti, 1982). The final treatment consisted of reacting with $0.001 \mathrm{M} \mathrm{HClO}_{4}$ followed by repeated washing with bidistilled water (until constant conductivity was observed) and lyophilization. The whole procedure took usually several days. Hence the term 'freshly prepared' as used below refers to a moderately aged (2-5 days old) sample. The so obtained $\mathbf{H}$-clay is not stable (Ferris \& Jepson, 1975). Titration curves of samples that had been stored for 4 months differed significantly from curves obtained with freshly prepared samples. The curves discussed in this report reflect the properties of freshly prepared $\mathrm{H}$-kaolinite. BET surface area $S=10200 \mathrm{~m}^{2} / \mathrm{kg}$. Total amount of ionizable groups (estimated according to Schindler \& Kamber, 1968): $\mathrm{S}^{\circ}=5.55 \mathrm{E}-2 \mathrm{~mol} / \mathrm{kg}$.

$\mathrm{NaClO}_{4}$ was prepared from $\mathrm{HClO}_{4}$ and $\mathrm{Na}_{2} \mathrm{CO}_{3}$ (analytical grade, Merck) as described earlier (Santschi \& Schindler, 1974). Stock solutions of $\mathrm{Cu}\left(\mathrm{ClO}_{4}\right)_{2}$, $\mathrm{Cd}\left(\mathrm{ClO}_{4}\right)_{2}$ and $\mathrm{Pb}\left(\mathrm{ClO}_{4}\right)_{2}$ were obtained from analytical grade $\mathrm{CuO}, \mathrm{CdCO}_{3}, \mathrm{PbO}$ and $\mathrm{HClO}_{4}$ and standardized against EDTA. Solutions of $\mathrm{NaOH}$ were prepared from Titrisol (Merck) and standardized coulometrically.

\section{Electromotive force measurements}

The concentrations of hydrogen ions and metal ions were obtained with the aid of the cells

$\mathrm{RE} / \mathrm{I} \mathrm{M} \mathrm{NaClO}_{4} /$ glass electrode

$\mathrm{RE} / \mathrm{I} \mathrm{M} \mathrm{NaClO}{ }_{4} / \mathrm{M}^{2+}$-sensitive electrode

where $\mathrm{RE}$ is the reference electrode

$\mathrm{Ag}, \mathrm{AgCl} / 0.01 \mathrm{I} \mathrm{M} \mathrm{NaCl}, 0.99 \mathrm{I} \mathrm{M} \mathrm{NaClO}_{4}$.

Metrohm (EA 109) glass electrodes and Orion ion-sensitive electrodes were used. A Wilhelm-type salt bridge (Forsling et al., 1952) was used to connect test solution and reference electrode. Under the prevailing experimental conditions, variations in the liquid junction potential between the salt bridge and the test solutions could be neglected. The emf of the cells are thus given by

$$
\begin{aligned}
& \mathrm{E}_{\mathrm{a}}=\mathrm{E}_{\mathrm{a}}^{\mathrm{o}}+\mathrm{k}_{\mathrm{a}} \log \left[\mathrm{H}^{+}\right] \\
& \mathrm{E}_{\mathrm{b}}=\mathrm{E}_{\mathrm{b}}^{\mathrm{o}}+\mathrm{k}_{\mathrm{b}} \log \left[\mathrm{M}^{2+}\right]
\end{aligned}
$$

$E_{a}^{o}, k_{a}, E_{b}^{o}$ and $k_{b}$ were obtained from separate calibrations. It should be emphasized that the quantity obtained from emf measurements with cell a is the hydrogen ion concentration. The $\mathrm{pH}$ values as used in this report are defined by

$$
\mathrm{pH}=-\log \left[\mathrm{H}^{+}\right] \mathrm{y}_{\mathrm{H}}
$$

where $y_{H}$ is the activity coefficient of the hydrogen ions obtained from the Davies equation (see below). 


\section{Auxiliary contants}

Stability constants of the hydroxo complexes of $\mathrm{Cu}^{2+}, \mathrm{Cd}^{2+}$ and $\mathrm{Pb}^{2+}$ were taken from Baes \& Mesmer (1976).

\section{Results and discussion}

The titration curves of $\mathrm{H}$-kaolinite (Fig. 1) display two buffer regions separated by approximately $1.5 \mathrm{pH}$ units. This indicates the presence of two kinds of acidic groups. The adsorption data (Figs. 2-4) show a striking effect of the ionic strength, i.e. of the prevailing sodium concentration. At low $\mathrm{pH}$ values the sodium ions can successfully compete with the divalent metal ions and $\mathrm{NaClO}_{4}$ suppresses adsorption up to $\mathrm{pH} 4.5(\mathrm{Cu}(\mathrm{II}), \mathrm{Pb}(\mathrm{II}))$ and $\mathrm{pH} 6(\mathrm{Cd}(\mathrm{II}))$ respectively. At higher $\mathrm{pH}$ values, however, even high concentrations of background electrolyte cannot prevent the divalent metal ions from being adsorbed. These observations suggest two different sites for $\mathrm{M}$ (II) binding. We thus postulate that the kaolinite sample contains

- weakly acidic groups $\mathrm{XH}$ which are able to undergo ion exchange with both $\mathrm{Na}^{+}$ and $\mathrm{M}^{2+}$ ions. The total concentration of these groups is obtained from Fig. 1: $\{\mathrm{XH}\}_{1}=1.56 \mathrm{E}-2 \mathrm{moles} / \mathrm{kg}$.

- ampholytic surface hydroxyls $\mathrm{SOH}$ which can bind and release protons (to give $\mathrm{SO}^{-}$and $\mathrm{SOH}_{2}^{+}$) and to form inner sphere complexes $\mathrm{SOM}^{+}$and $(\mathrm{SO})_{2} \mathrm{M}$. In addition, they are assumed to bind $\mathrm{Na}^{+}$by forming a weak outer sphere complex $\mathrm{SO}^{-} \mathrm{Na}^{+}$. The total concentration of $\mathrm{SOH}$ groups is

$$
\{\mathrm{SOH}\}_{\mathrm{t}}=\mathrm{S}^{\mathrm{o}}-\{\mathrm{XH}\}_{\mathrm{t}}=3.99 \mathrm{E}-2 \text { moles } / \mathrm{kg}
$$

Specifically we postulate the following equilibria:

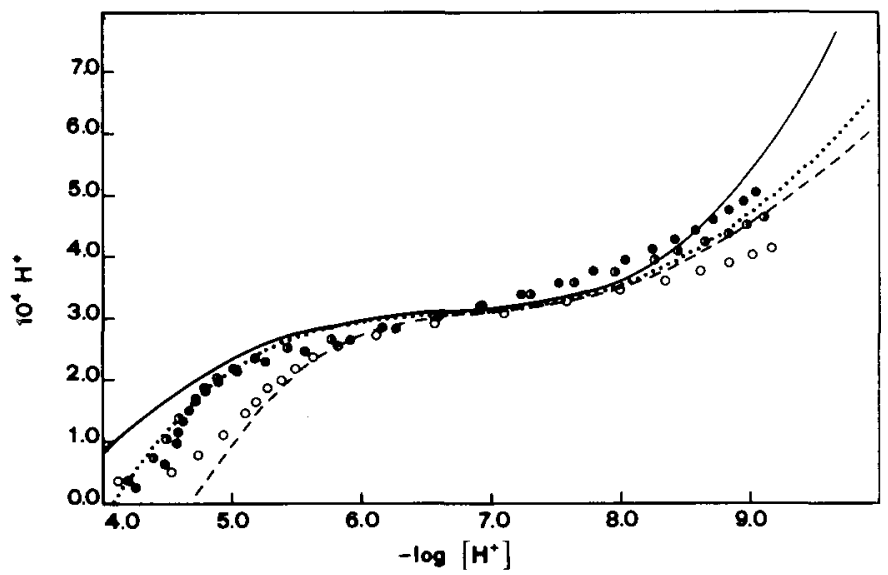

Fig. 1. Titration of $\mathrm{H}-\mathrm{kaOlinite}$ with $\mathrm{NaOH}: \mathrm{H}^{*}$ as a function of $\log \left[\mathrm{H}^{+}\right]$. The drawn lines are calculated with the constants given in Table $1 . \mathrm{I}=0.01$ : --- and open circles; $\mathrm{I}=0.1 \ldots$ and half-filled circles; $\mathrm{I}=1.0 \mathrm{x}-$ and filled circles. 


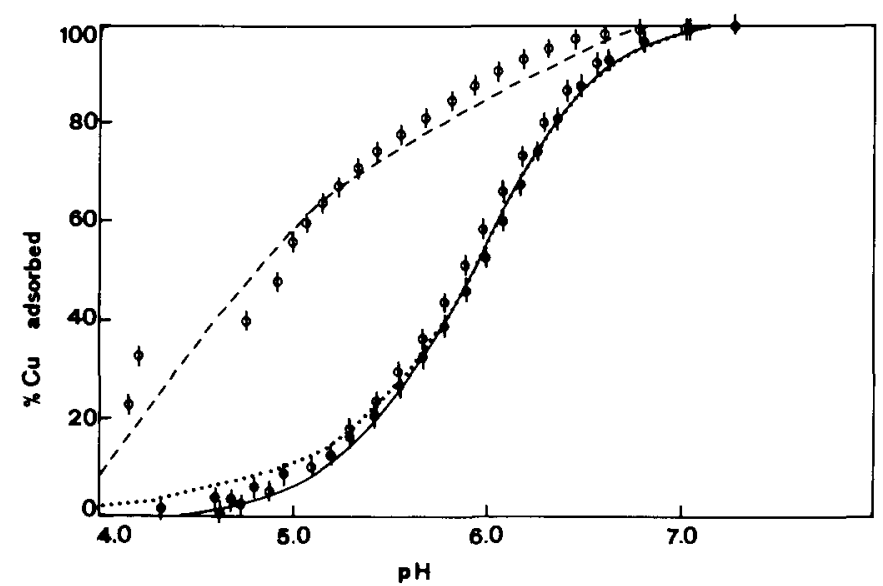

Fig. 2. Adsorption of $\mathrm{Cu}(\mathrm{II})$ by kaolinite as a function of $\log \left[\mathrm{H}^{+}\right]$. The drawn lines are calculated with the constants given in Table 1. For explanation of symbols, see Fig. 1.

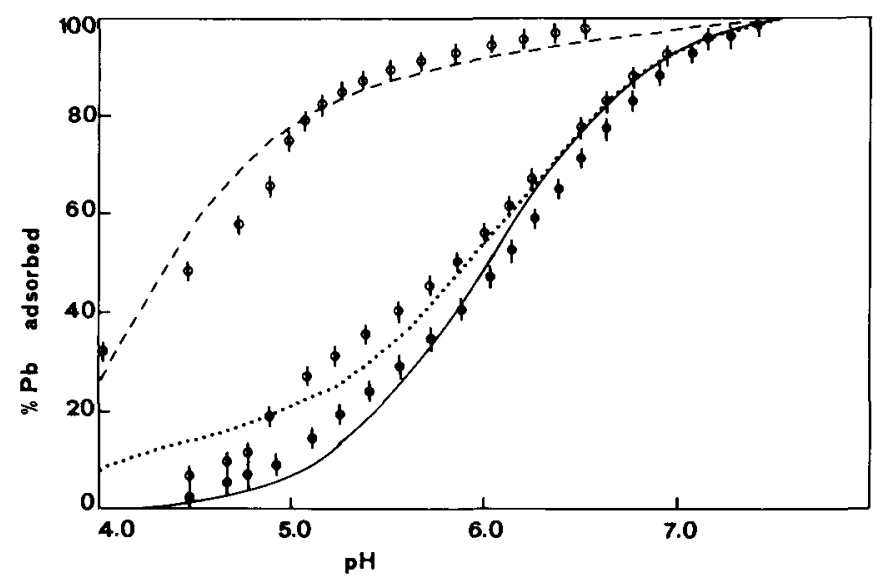

Fig. 3. Adsorption of $\mathrm{Pb}(\mathrm{II})$ by kaolinite as a function of $\log \left[\mathrm{H}^{+}\right]$. The drawn lines are calculated with the constants given in Table 1. For explanation of symbols, see Fig. 1.

$$
\begin{aligned}
& \mathrm{XNa}+\mathrm{H}^{+}=\mathrm{XH}+\mathrm{Na}^{+} \\
& \mathrm{K}_{1}=\{\mathrm{XH}\}\left[\mathrm{Na}^{+}\right] \mathrm{y}_{\mathrm{Na}} /\{\mathrm{XNa}\}\left[\mathrm{H}^{+}\right] \mathrm{y}_{\mathrm{H}} \\
& 2 \mathrm{XNa}+\mathrm{M}^{2+}=\mathrm{X}_{2} \mathrm{M}+2 \mathrm{Na}^{+} \\
& \mathrm{K}_{2}=\left\{\mathrm{X}_{2} \mathrm{M}\right\}[\mathrm{Na}]^{2} \mathrm{y}_{\mathrm{Na}}^{2} /\{\mathrm{XNa}\}^{2}\left[\mathrm{M}^{2+}\right] \mathrm{y}_{\mathrm{M}} \\
& \mathrm{SOH}+\mathrm{Na}^{+}=\mathrm{SONa}+\mathrm{H}^{+}
\end{aligned}
$$




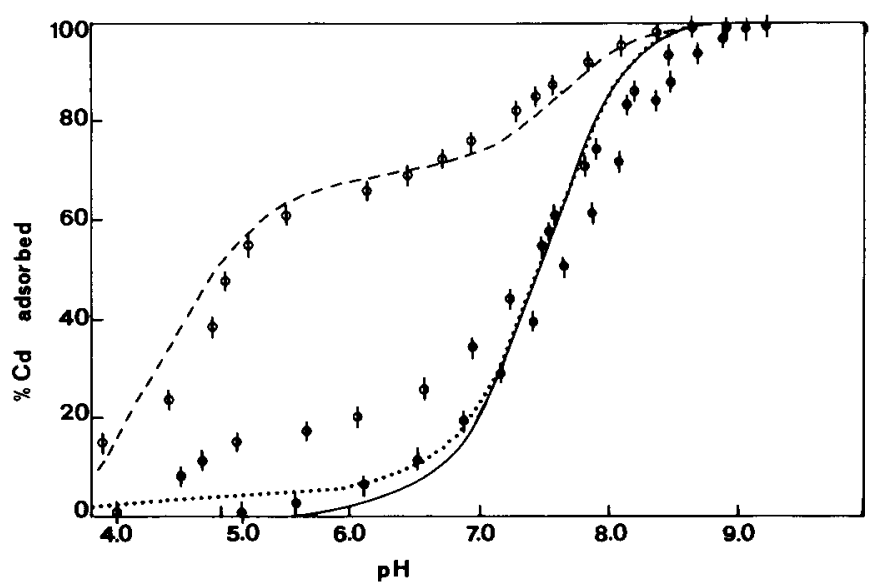

Fig. 4. Adsorption of $\mathrm{Cd}(\mathrm{II})$ by kaolinite as a function of $\log \left[\mathrm{H}^{+}\right]$. The drawn lines are calculated with the constants given in Table 1. For explanation of symbols, see Fig. 1.

$$
\begin{aligned}
& \mathrm{K}_{3}=\{\mathrm{SONa}\}\left[\mathrm{H}^{+}\right] \mathrm{y}_{\mathrm{H}} /\{\mathrm{SOH}\}\left[\mathrm{Na}^{+}\right] \mathrm{y}_{\mathrm{Na}} \\
& \mathrm{SOH}_{2}^{+}=\mathrm{SOH}+\mathrm{H}^{+} \\
& * \mathrm{~K}_{\mathrm{a} 1}^{\mathrm{s}}=\{\mathrm{SOH}\}\left[\mathrm{H}^{+}\right] \mathrm{y}_{\mathrm{H}} \exp (-\mathrm{F} \psi / \mathrm{RT}) /\left\{\mathrm{SOH}_{2}^{+}\right\} \\
& \mathrm{SOH}=\mathrm{SO}^{-}+\mathrm{H}^{+} \\
& * \mathrm{~K}_{\mathrm{a} 2}^{\mathrm{s}}=\left\{\mathrm{SO}^{-}\right\}\left[\mathrm{H}^{+}\right] \mathrm{y}_{\mathrm{H}} \exp (-\mathrm{F} \psi / \mathrm{RT})\{\mathrm{SOH}\} \\
& \mathrm{SOH}+\mathrm{M}^{2+}=\mathrm{SOM}^{+}+\mathrm{H}^{+} \\
& * \mathrm{~K}_{1}^{\mathrm{s}}=\left\{\mathrm{SOM}^{+}\right\}\left[\mathrm{H}^{+}\right] \mathrm{y}_{\mathrm{H}} \exp (\mathrm{F} \psi / \mathrm{RT}) /\{\mathrm{SOH}\}\left[\mathrm{M}^{2+}\right] \mathrm{y}_{\mathrm{M}} \\
& 2 \mathrm{SOH}+\mathrm{M}^{2+}=(\mathrm{SO})_{2} \mathrm{M}+2 \mathrm{H}^{+} \\
& * \beta_{2}^{\mathrm{s}}=\left\{(\mathrm{SO})_{2} \mathrm{M}\right\}\left[\mathrm{H}^{+}\right]^{2} \mathrm{y}_{\mathrm{H}}^{2} /\{\mathrm{SOH}\}^{2}\left[\mathrm{M}^{2+}\right] \mathrm{y}_{\mathrm{M}}
\end{aligned}
$$

where $\psi$ stands for the acting surface potential. $\psi$ was calculated on the basis of the constant capacitance model (Schindler \& Gamsjäger, 1972):

$$
\psi=\left(\left\{\mathrm{SOH}_{2}^{+}\right\}+\left\{\mathrm{SOM}^{+}\right\}-\left\{\mathrm{SO}^{-}\right\}\right) * \mathbf{F} / \mathbf{S} * \kappa,
$$

where $\mathrm{F}$ is the Faraday constant and $\kappa$ is the specific capacitance. The activity coefficients of the dissolved species were obtained from the Davies equation (Davies, 1962, p. 41) 
Table 1. Equilibrium constants $298.2 \mathrm{~K}, \mathrm{I}=0$.

\begin{tabular}{|c|c|c|c|}
\hline \multirow[t]{2}{*}{$\begin{array}{l}\log K_{1} \\
\log K_{a 1}^{s}\end{array}$} & $\begin{array}{l}=2.9 \\
=-4.37\end{array}$ & $\begin{array}{l}\log K_{3}=-9.84 \\
\log K_{\mathrm{a} 2}^{\mathrm{s}}=-9.18\end{array}$ & \\
\hline & $\mathrm{Cu}(I I)$ & $C d(I I)$ & $P b(I I)$ \\
\hline $\log \mathrm{K}_{2}$ & 2.39 & 2.27 & 2.98 \\
\hline $\mathbf{K}_{\mathrm{v}}$ & 3.83 & 2.90 & 14.9 \\
\hline $\log * K_{1}^{s}$ & -2.50 & -4.29 & -2.45 \\
\hline $\log * \beta_{2}^{\mathrm{s}}$ & -7.46 & -10.4 & -8.11 \\
\hline
\end{tabular}

$$
\log y_{i}=-0.5 z_{i}^{2}\left(I^{1 / 2} /\left(1+I^{1 / 2}\right)-0.31\right) .
$$

The activity coefficients of the surface species were assumed to be unity. The equilibrium constants were evaluated with the aid of a HP-85 adapted version of FITEQL (Westall, 1982). In a first step, the constants $\mathrm{K}_{1}, \mathrm{~K}_{3}, \mathrm{~K}_{\mathrm{a} 1}^{\mathrm{s}}$ and $\mathrm{K}_{\mathrm{a} 2}^{\mathrm{s}}$ were evaluated from the data shown in Fig. 1. The calculations were performed with different values for the specific capacitance $\kappa$. The best fit was obtained with $\kappa=2.2$ fa$\mathrm{rad} / \mathrm{m}^{2}$. In the subsequent steps, the equilibrium constants related to $\mathrm{M}$ (II) uptake were evaluated. The obtained values are shown in Table 1. Figures 1-4 indicate that the chosen model gives an acceptable (although not perfect) fit of the experimental data. Systematic errors may originate from

- non-ideal behaviour of the adsorbed species;

- extending the validity range of the Davies equation up to ionic strength 1 ;

- selecting the same double-layer model and even the same value for the specific capacitance for solutions of very different ionic strength.

Furthermore, the introduction of just two kinds of adsorbing sites is an oversimplification that does not allow for the heterogeneity of the clay. The suitability of a model cannot just be measured by its ability to fit a given set of experimental data. In addition the observed values for the constants of the postulated equilibria must be in accordance with related observations. We therefore compare the properties of the postulated groups $\mathrm{XH}$ and $\mathrm{SOH}$ (as exhibited by the corresponding equilibria) with properties of ion exchanging groups at clays and with surface hydroxyls at alumina and silica.

\section{The nature of the $X H$ groups}

The constants $\mathrm{K}_{2}$ that describe the ion exchange $\mathrm{M}^{2+}-\mathrm{Na}^{+}$are related to the more familiar Vanselow coefficients $K_{v}$ by

$$
\mathrm{K}_{\mathrm{v}}=\mathrm{K}_{2}\left(\{\mathrm{NaX}\}+\left\{\mathrm{MX}_{2}\right\}\right) \approx 1.56 \mathrm{E}-2 \mathrm{~K}_{2} .
$$

The observed values for $\mathrm{K}_{\mathrm{v}}$ (Table 1) are somewhat higher than corresponding values reported for montmorillonite (Bruggenwert \& Kamphorst, 1982; Sposito et al., 1981). For the exchange 


\section{Cd-kaolinite $+\mathrm{Pb}^{2+}=\mathrm{Pb}-\mathrm{kaolinite}+\mathrm{Cd}^{2+}$}

however, the reported value of $\mathrm{K}_{\mathrm{ex}}=0.31$ ( \pm 0.1 ) (Bittell \& Miller, 1974) is in fair agreement with the present results (Table 1): $\mathrm{K}_{\mathrm{ex}}=\mathrm{K}_{\mathrm{v}}(\mathrm{Cd}) / \mathrm{K}_{\mathrm{v}}(\mathrm{Pb})=0.19$. This would indicate that the ion exchange properties of the kaolinite sample are actually represented by the groups $\mathrm{XH}$. On the other hand, $\mathrm{K}_{1}$ is much larger than reported values for similar systems $\left(K_{1} \approx 1\right)$. This could mean that the assumed $\mathrm{H}$-clay is actually a ( $\mathrm{H}-\mathrm{Al})$-clay, a possibility that would be consistent with the actual age of our 'freshly prepared' samples. The left hand side part of the titration curve (Fig. 1) would then describe the $\mathrm{Na}^{+}-\mathrm{Al}^{3+}$ exchange and the subsequent hydrolysis of $\mathrm{Al}^{3+}$. The comparatively high value of $\mathrm{K}_{\mathrm{a} 1}$ would then at least partially be related to the first hydrolysis constant of $\mathrm{Al}^{3+}\left(\log * \mathrm{~K}_{1} \approx-5\right)$. Our present data do not permit to unambiguously distinguish between the two possibilities. Further work is planned.

In addition, the question whether the $\mathrm{XH}$ or $\mathrm{X}(\mathrm{H}, \mathrm{Al})$ groups identified in our kaolinite sample are to be ascribed to isomorphous substitution or to contamination with very small amounts of 2:1 phyllosilicates (Talibudeen, 1984) must be left open.

\section{The nature of the SOH groups}

The stabilities of the surface complexes of $\mathrm{Cu}(\mathrm{II})$ and $\mathrm{Pb}$ (II) with deprotonated $\mathrm{SiOH}$ and $\mathrm{AlOH}$ groups (Table 2, Schindler \& Stumm, 1987) are comparatively well known. The comparison with the corresponding values for the kaolinite sample suggests that the postulated $\mathrm{SOH}$ groups can be identified as $\mathrm{Al}-\mathrm{OH}$ groups.

\section{Surface speciation: relative importance of the individual processes}

Fig. 5 displays the surface speciation of kaolinite for a system consisting of $1 \mathrm{~g}$ of kaolinite suspended in $0.05 \mathrm{dm}^{3}$ of $1 . \mathrm{E}-4 \mathrm{M} \mathrm{Cu}\left(\mathrm{ClO}_{4}\right)_{2}$ solutions of different ionic strengths (Systems with $\mathrm{Cd}(\mathrm{II})$ and $\mathrm{Pb}$ (II) are similar.) First, we note that in the chosen $\mathrm{pH}$ range only seven out of the nine postulated surface species are of importance. The concentrations of $\mathrm{SO}^{-}$and $\mathrm{SOH}$ remain marginal. The important feature seen from Fig. 5 is the demonstration of how the relative importance of ion exchange and surface complexation is governed by the prevailing ionic strength, i.e. by the concentration of the sodium ions. At $\mathbf{I}=0.01$ (what is approximately the ionic strength of soil solutions and fresh waters) and for $\mathrm{Cu}(\mathrm{II})$, ion exchange domi-

Table 2. Stability constants of surface complexes with $\mathrm{AlOH}$ and $\mathrm{SiOH}$ groups (Schindler \& Stumm, 1987).

$\mathrm{Cu}(\mathrm{II}) \quad \mathrm{Pb}(\mathrm{II})$

$\begin{array}{llll}A l O H & & & \\ \log * \mathrm{~K}_{1}^{\mathrm{s}} & \left(0.1 \mathrm{M} \mathrm{NaClO}_{4}\right) & -2.1 & -2.2 \\ \log * \beta_{2}^{\mathrm{s}} & \left(0.1 \mathrm{M} \mathrm{NaClO}_{4}\right) & -7.0 & -8.1 \\ & & & \\ \mathrm{SiOH} & & -5.52 & -5.09 \\ \log * \mathrm{~K}_{1}^{\mathrm{s}} & \left(1 \mathrm{M} \mathrm{NaClO}_{4}\right) & -11.19 & -10.68 \\ \log * \beta_{2}^{\mathrm{s}} & \left(1 \mathrm{M} \mathrm{NaClO}_{4}\right) & & \end{array}$




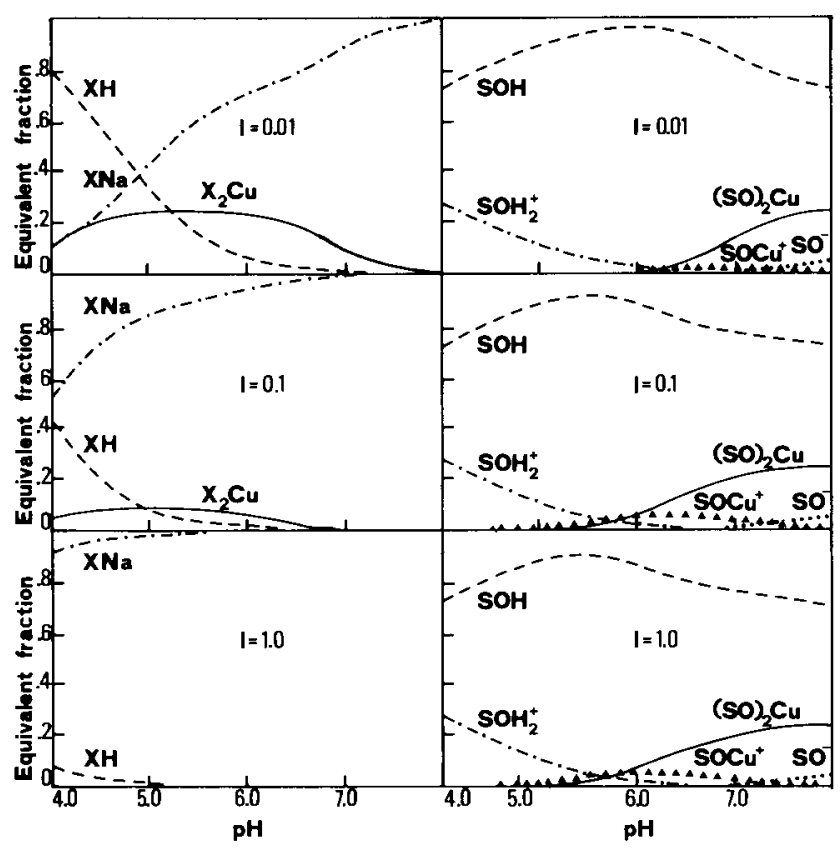

Fig. 5. Surface speciation in the system $\mathrm{Cu}(\mathrm{II})-\mathrm{NaClO}_{4-}-$ kaolinite as a function of $\mathrm{pH}$ and $\mathrm{I}:[\mathrm{Cu}(\mathrm{II})]_{\mathrm{t}}=$ 1.E-4 M, A/Vo $=0.02 \mathrm{~kg} / \mathrm{dm}^{3}$.

nates up to a $\mathrm{pH}$ value of 6.5 . At $\mathrm{I}=1$ (and thus, for instance, in sea water) uptake by ion exchange is negligibly small. Finally, it is seen that the relative contributions of the surface complexes $\mathrm{SOCu}^{+}$and $(\mathrm{SO})_{2} \mathrm{Cu}$ are dependent on $\mathrm{I}$ in so far as $\mathrm{SOCu}^{+}$is unimportant at low ionic strength.

\section{Conclusions}

The uptake of heavy metal ions by kaolinite from solutions of various ionic strengths and $\mathrm{pH}$ values can approximately be described by a model that assumes two kinds of binding sites:

a) weakly acidic sites XH capable to undergo ion exchange and thus unspecific adsorption;

b) ampholytic surface hydroxyls AlOH responsible for specific adsorption by formation of inner sphere complexes.

The model calculations suggest that ion exchange is important at low $\mathrm{pH}$ values and low ionic strength whereas an increase in both ionic strength and $\mathrm{pH}$ value favor specific adsorption.

\section{Acknowledgements}

The work was financially supported by the Swiss National Science Foundation. 


\section{References}

Baes, Ch. F. Jr. \& R. E. Mesmer, 1976. The hydrolysis of cations. Wiley, New York, 489 pp.

Bittell, J. E. \& R. J. Miller, 1974. Lead, cadmium, and calcium selectivity coefficient on a montmorillonite, illite and kaolinite. Journal of Environmental Quality 3: 250-253.

Bruggenwert, M. G. M. \& A. Kamphorst, 1982. Survey of experimental information on cation exchange in soil systems. In: G. H. Bolt (Ed.), Soil chemistry. B. Physico-chemical models, 2nd ed., p. 141-203. Elsevier, Amsterdam.

Davies, C. W., 1962. Ion association. Butterworths, London, $190 \mathrm{pp}$.

Dillard, J. G. \& M. H. Koppelman, 1982. X-ray photoelectron spectroscopic (XPS) surface characterization of cobalt on the surface of kaolinite. Journal of Colloid and Interface Science 87: 46-55.

Ellis, B. G. \& B. D. Knezek, 1972. Adsorption reactions of micronutrients in soils. In: J. J. Mortvedt, P. M. Giordano \& W. L. Lindsay (Eds.), Micronutrients in agriculture, p. 59-78. Soil Science Society of America, Madison, WI, USA.

Farrah, H., D. Hatton \& W. F. Pickering, 1980. The affinity of metal ions for clay surfaces. Chemical Geology 28: 55-68.

Ferris, A. P. \& W. B. Jepson, 1975. The exchange capacities of kaolinite and the preparation of homoionic clays. Journal of Colloid and Interface Science 51: 245-259.

Forsling, W., S. Hietanen \& L. G. Sillén, 1952. Studies on the hydrolysis of metal ions. III. The hydrolysis of the mercury(I) ion $\mathrm{Hg}_{2}^{2+}$. Acta Chemica Scandinavica 6: 901-909.

Liechti, P., 1982. Adsorption von Metallionen an der Grenzfläche Kaolinit-Wasser. Ph.D. thesis, University of Bern.

Lindsay, W. L., 1972. Inorganic phase equilibria of micronutrients in soils. In: J. J. Mortvedt, P. M. Giordano \& W. L. Lindsay (Eds.), Micronutrients in agriculture, p. 41-57. Soil Science Society of America, Madison, WI, USA.

Lindsay, W. L. . 1979. Chemical equilibria in soils. Wiley, New York, 449 pp.

McBride, M. B., 1976. Origin and position of exchange sites in kaolinite: an esr study. Clays and Clay Minerals 24: 88-92.

Menzel, R. G. \& M. L. Jackson, 1951. Mechanism of sorption of hydroxy cupric ions by clays. Soil Science Society of America Proceedings 15: 122-124.

Santschi, P. \& P. W. Schindler, 1974. Complex formation in the ternary systems $\mathrm{Ca}(\mathrm{II})-\mathrm{H}_{4} \mathrm{SiO}_{4}-\mathrm{H}_{2} \mathrm{O}$ and $\mathrm{Mg}(\mathrm{II})-\mathrm{H}_{4} \mathrm{SiO}_{4}-\mathrm{H}_{2} \mathrm{O}$. Journal of the Chemical Society, Dalton Transactions 2: 181-184.

Schindler, P. W. \& H. R. Kamber, 1968. Die Azidität von Silanolgruppen. Helvetica Chimica Acta 51: 1781-1786.

Schindler, P. W. \& H. Gamsjäger, 1972. Acid-base reactions of the $\mathrm{TiO}_{2}$ (anatase)-water interface and the point of zero charge of $\mathrm{TiO}_{2}$-suspensions. Kolloid Zeitschrift und Zeitschrift für Polymere 250: 759763.

Schindler, P. W., 1981. Surface complexes at oxide-water interfaces. In: M. A. Anderson \& A. J. Rubin (Eds.), Adsorption of inorganics at solid-liquid interfaces, p. 1-47. Ann Arbor Science Publishers, Ann Arbor, MI, USA.

Schindler, P. W., 1984. Surface complexation. In: H. Sigel (Ed.), Metal ions in biological systems, Vol. 18, Circulation of metals in the environment, p. 105-135. Marcel Dekker, New York.

Schindler, P. W. \& W. Stumm, 1987. The surface chemistry of oxides, hydroxides and oxide minerals. In: W. Stumm (Ed.), Aquatic surface chemistry, p. 83-110. Wiley Interscience, New York.

Sposito, G., K. M. Holtzclaw, C. T. Johnston \& C. S. LeVesque-Madore, 1981. Thermodynamics of the sodium-copper exchange on Wyoming-bentonite at $298 \mathrm{~K}$. Soil Science Society of America Journal 45: 1079-1084.

Sposito, G., 1984a. Cycling of metal ions in the soil environment. In: H. Sigel (Ed.), Metal ions in biological systems, Vol. 18, Circulation of metals in the environment, p. 287-331. Marcel Dekker, New York.

Sposito, G., 1984b. The surface chemistry of soils. Oxford University Press, New York, 234 pp.

Talibudeen. O., 1984. Charge heterogeneity and the calorimetry of K-Ca exchange-adsorption in clays and soils. Adsorption Science \& Technology 1: 235-246.

Tiller, K. G., 1986. Essential and toxic heavy metals in soils and their ecological relevance. Transactions 13th Congress of the International Society of Soil Science (Hamburg), Vol. I, p. 29-44. 


\section{P. W. SCHINDLER, P. LIECHTI AND J. C. WESTALL}

Westall, J. C., 1982. FITEQL, a computer program for determination of chemical equilibrium constants from experimental data. Report 82-01, Chemistry Department, Oregon State University, Corvallis, OR, USA.

Westall, J. C., 1986. Reactions at the oxide-solution interface: chemical and electrostatic models. In: J. A. Davis \& K. F. Hayes (Eds.), Geochemical processes at mineral surfaces. American Chemical Society, Washington, DC, USA 